\title{
A Geospatial Morphometric Analysis of Kulbera and Daurighara River Basins in Western Part of Purulia District of West Bengal, India
}

\author{
Shambhu Nath Sing Mura
}

\begin{abstract}
Morphometric analysis is used to understand the hydrological process and assessment of hydrological characteristics of surface water basin. In the present paper, an attempt has been made to study the detail morphometric characteristics of Kulbera and Daurighara river basin, which are tributaries of Subarnarekha River in Purulia district, West Bengal. For detailed study, SRTM data has been used for preparing digital elevation model (DEM), and Geographic Information System (GIS) has been used for the analysis of linear, areal, and relief aspects of the basins. Watershed boundary, flow accumulation, flow length, stream ordering have been prepared by using ILWIS 3.0. Different thematic maps i.e. elevation, geology, drainage density, slope and longitudinal profiles of river channels have been prepared by using QGIS 3.0 and MapInfo 10.0 GIS software. More than 58 morphometric parameters of all aspects of the basins have been computed. On the basis of morphometric analysis it has been argued that the erosional development has progressed well beyond maturity and that the drainage development is controlled by lithology. Besides, it can be concluded that this study will also be very useful for rain water harvesting planning and watershed management.
\end{abstract}

Keywords : Morphometric Analysis, SRTM (DEM), Kulbera \& Daurighara and RSGIS.

\section{INTRODUCTION}

$\mathrm{W}$ ater is a valuable resource and an essential human need. Demands of water already exceed supply in many parts of the world and many more areas are expected to experience the imbalance of demand and supply in the near future. Climate change will have significant impacts on water resources around the world because of the close connections between the climate and hydrological cycle. Watershed management plays an important role of it and watershed morphometry study is an important aspect in its management [1- 4]. Morphometry analysis of a watershed is helpful in understanding the impact of stream morphometry. Morphometry analysis is the measurement and mathematical analysis of the configuration of the Earth's surface, shape and dimension of its landforms [5-6]. Morphometric analysis tool and technique is one of the most important to determine and evaluate drainage basin responses to climate change and drainage characteristics [7], flash flood hazard [8], and

Manuscript received on February 15, 2021.

Revised Manuscript received on February 22, 2021.

Manuscript published on February 28, 2021.

* Correspondence Author

Dr. Shambhu Nath Sing Mura*, Department, of Geography Vivekananda Mahavidyalaya, Burdwan, West Bengal, India. Email: shambhu.vmbwn@gmail.com

(C) The Authors. Published by Blue Eyes Intelligence Engineering and Sciences Publication (BEIESP). This is an open access article under the CC BY-NC-ND license (http://creativecommons.org/licenses/by-nc-nd/4.0/) hydrological processes [9]. Flood analysis in the river basins needs geomorphological parameters which govern the hydrological response of the river basin [10]. The morphometric characteristics at the watershed scale may contain important information regarding its formation and development because all hydrologic and geomorphic processes occur within the watershed. Morphometric analysis of a watershed provides a quantitative description of the drainage system, which is an important aspect of the characterization of watershed [11]. Remote sensing technique has been developed for the analysis of the stream morphometry and it is a powerful tool in recent past. Remote sensing has the capacity to get information for an extensive and remote zones and it is also a very useful technique in analyzing the morphometry in any drainage system. Remote sensing and GIS techniques have developed as an effective tool for the watershed development programmes. Morphometry analysis is used in watershed prioritization and it helps to understand hydrological characteristics of the watershed like structure, relief of the watershed, stream network, platform and topology [12-14]. Linear features, areal aspects, gradient of channel network and ground slope of the drainage basin are required for morphometric analysis. Watershed is used as a basic unit for morphometric analysis in a logical choice. Remote sensing and Geographical Information System (GIS) is a powerful tool in recent years, which plays a vital role for understanding the hydrogeological conditions, prevailing climate, geological structure and geomorphology of the drainage basin [15]. Geographical Information System (GIS) technique is a much efficient and time saving technique which are suitable for spatial planning. Manipulation and retrieval of large data base can be handled by the GIS more effectively. It can also solve many complex issues besides facilitating retrieval and querying of data [16]. Morphometry characteristics of the basin help us for the management of rainwater harvesting in the watershed.

\section{STUDY AREA}

Kulbera and Saurighara rivers are the tributary of Subarnarekha River and these basin are contiguous basin to each other. Kulbera and Daurighara river basins are covered an area of $118.50 \mathrm{sq}$. km. and $160.04 \mathrm{sq}$. km. respectively and the area is located between $23^{0} 06^{\prime} 45^{\prime \prime} \mathrm{N}$ to $23^{0} 16^{\prime} 56^{\prime \prime} \mathrm{N}$ latitude and $85^{\circ} 54^{\prime} 30^{\prime \prime} \mathrm{E}$ to $86^{\circ} 08^{\prime} 39^{\prime /} \mathrm{E}$ longitude (Figure 1 ).

Published By: and Sciences Publication 
Kulbera and Daurighara river basins are both flowing from the north east to south west direction and pouring into the Subarnarekha River. Kulbera River is $34 \mathrm{~km}$. long and elevation in the source is $\mathbf{5 4 3 . 6}$ meter.

On the other hand, Daurighara River is $34.7 \mathrm{~km}$. long and elevation in the source is 587.6 meter. The study area falls in Survey of India $(1: 50,000)$ toposheets number $73 E / 15$,

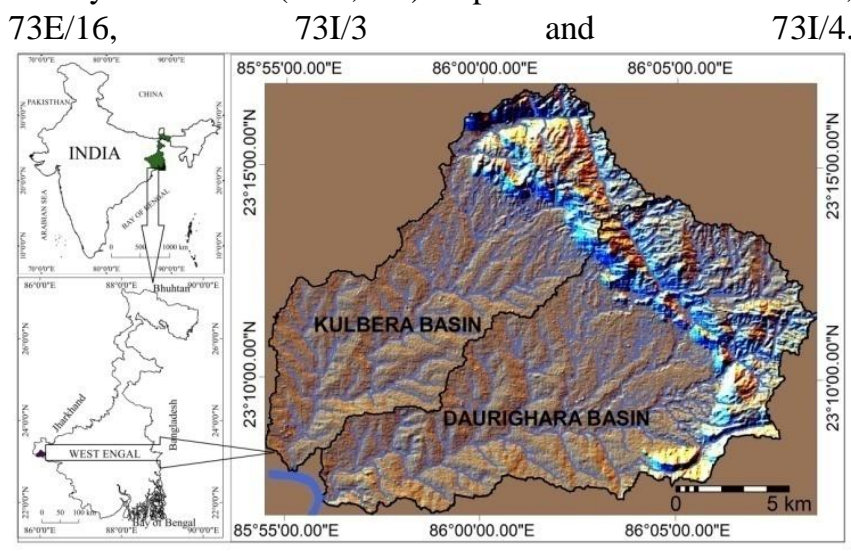

Fig. 1. Location of the Study Area

\section{DATA USED AND METHODOLOGY}

For the study of geomorphological feature in the river basin requires measurement and mathematical investigation of the configuration of the earth's surface and of the shape and dimensions of its landform [17-18]. The area, altitude, volume, slope, profile, length and texture of landforms are the principal parameters for the study of basin morphometry. The morphometry analysis of two contiguous watersheds was carried out individually using SRTM-DEM with $30 \mathrm{~m}$. spatial resolution in GIS platform. Drainage basin has been delineated with assigning stream order from the SRTM-DEM using GIS software ILWIS 3.0. A geohydro processing model has been used for evaluating the morphometry parameters. Kulbera and Daurighara river basins are the sub-basins of Subarnarekha River and it has been extracted from SRTM data using GIS software ILWIS 3.0 hydroprocessing tool. The length of the stream, stream order and area of the watershed were generated using Strahler's system using ILWIS 3.0 hydroprocessing tool. Geological map of Purulia district has been collected from the Geological Survey of India and it has been geo-referenced using QGIS 3.0 for preparing geological map of the study area. Study area of geological map has been extracted from the geo-referenced geological map. Elevation and slope map are prepared from the SRTM (DEM) data with 30 meter spatial resolution using ILWIS 3.0 GIS software. Author also used topographical maps such as 73E/15, 73E/16, 73I/3 and $73 \mathrm{I} / 4$ for extracting morphometric parameters of both watersheds. All the morphometry parameters of Kulbera and Daurighara watersheds have been extracted from SRTM-DEM with 30 meter resolution and topographical maps in the GIS platform. Author has compared 58 morphometry parameter of the study area and tries to achieve the goal of this research work.

\section{RESULT AND DISCUSSION}

\section{A. Geology}

Physiographically, the area is a part of Chhotanagpur Plateau and it has exposed metamorphic rocks of proterozoic age except for some linear belts where sedimentaries of Gondowana rocks are predominant. Figure-2 shows the geological characteristics of the study area. 57.21 percent and 35.64 percent area of Kulbera and Daurighara river basins are covered with granite-gneiss respectively. Recent alluvium is covered by 29.58 percent area of Kulbera river basin and 31.81 percent area of Daurighara river basin. Mica-schist covers 9.93 percent area of Kulbera basin and 28.89 percent area of Daurighara basin. Table 1 shows the detail percentage of area covered by rocks.

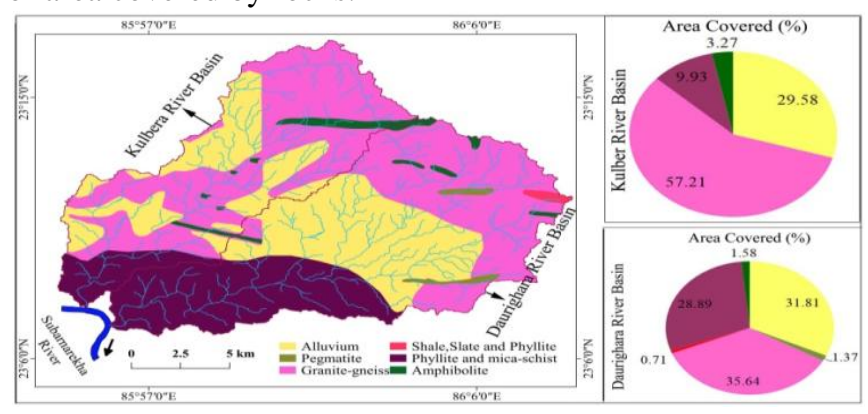

Source: Geological Survey of India, 1991 \& Author's Compilation

Fig. 2. Geology of the Study area

\section{B. Physiographic}

Elevation of the study area ranges from 128 meter to 646 meter from seal level. Figure-3 shows the elevation zones of the study area. Elevation of Kulbera basin ranges from 132 meter to 646 meter and Daurighara basin ranges from 128 meter to 601 meter from mean sea level. Elevation of the study area has been categorized into eleven zones at 50 meter interval. About 53 percent area is less than 200 meter and 47.10 percent area lies between 150 to 200 meter of Kulbera and Daurighara river basin respectively. Table 1 shows the elevation zone wise area of the study area.

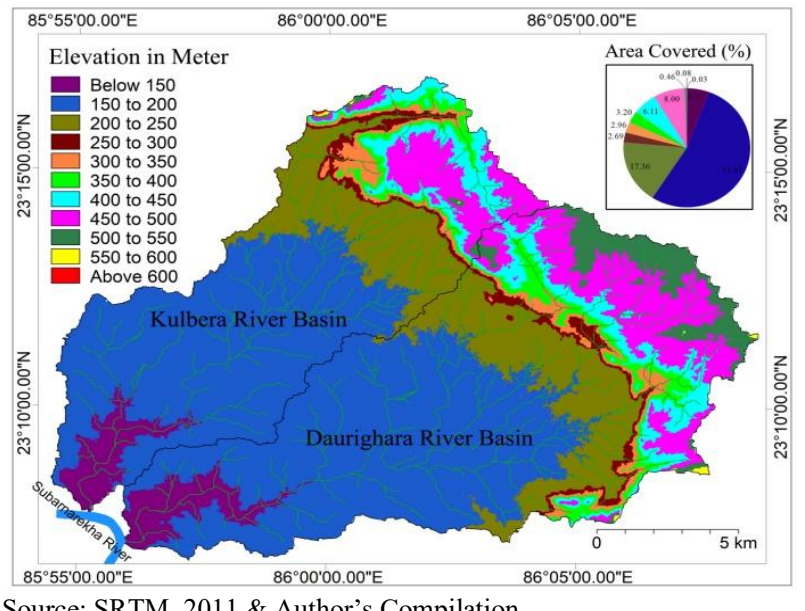

Source: SRTM, $2011 \&$ Author's Compilation

Fig. 3. Physiographic Division of the Study Area

Blue Eyes Intelligence Engineering

\& Sciences Publication

(C) Copyright: All rights reserved.

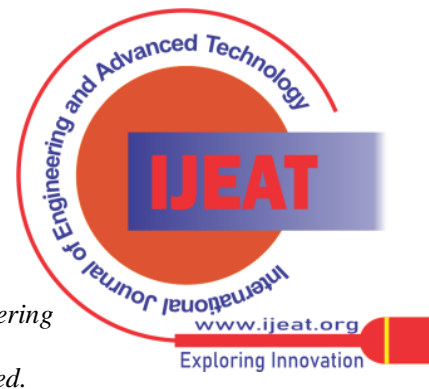


Table-I : Distribution of Elevation of the Study Area

\begin{tabular}{|c|c|c|}
\hline \multirow[b]{2}{*}{ Elevation (m) } & \multicolumn{2}{|c|}{ Area covered in percent } \\
\hline & $\begin{array}{c}\text { Kulbera } \\
\text { Basin }\end{array}$ & $\begin{array}{c}\text { Daurighara } \\
\text { Basin }\end{array}$ \\
\hline Below 150 & 5.71 & 4.78 \\
\hline 150 to 200 & 53.41 & 47.10 \\
\hline 200 to 250 & 17.36 & 15.53 \\
\hline 250 to 300 & 2.69 & 2.33 \\
\hline 300 to 350 & 2.96 & 2.44 \\
\hline 350 to 400 & 3.20 & 3.67 \\
\hline 400 to 450 & 6.11 & 5.64 \\
\hline 450 to 500 & 8.00 & 12.14 \\
\hline 500 to 550 & 0.46 & 6.23 \\
\hline 550 to 600 & 0.08 & 0.13 \\
\hline Above 600 & 0.03 & 0.00 \\
\hline
\end{tabular}

Source: Author's Compilation

\section{Slope}

A slope is the rise and fall of the land surface. It is important for the planners and engineers. Slope map has been prepared from the SRTM (DEM) data using ILWIS 3.0 GIS software. Using the following formula, slope has been calculated as given below-

SLOPDEG = RADDEG(ATAN(SLOPEPCT/100))

Where, SLOPDEG = Slope in Degree

RADDEG/ATAN = Internal map calculation of ilwis

SLOPEPCT $=100 *$ HYP(DX,DY)/Pixel size $($ DEM)

HYP = Internal map calculation

$\mathrm{DX}=$ Height difference in $\mathrm{X}$-direction

DY $=$ Height difference in $\mathrm{Y}$-direction

Slope of Kulbera and Daurighara river basin have been categorized in eleven classes at $5^{0}$ intervals (Figure 4). Most of the area of both the basins is less than five degree of slope. 75.70 percent area of Kulbera river basin is below $5^{0}$ slopes on the other hand, 69.99 percent area is under below $5^{0}$ slope of Daurighara river basin. 10.61 and 15.18 percent area lies between $5^{0}$ to $10^{0}$ slope of Kulbera and Daurighara basin respectively. Very steep slope has been seen in south-east linear direction of the upper part of both basins. Figure 4 shows the slope distribution of Kulbera and Daurighara watersheds.

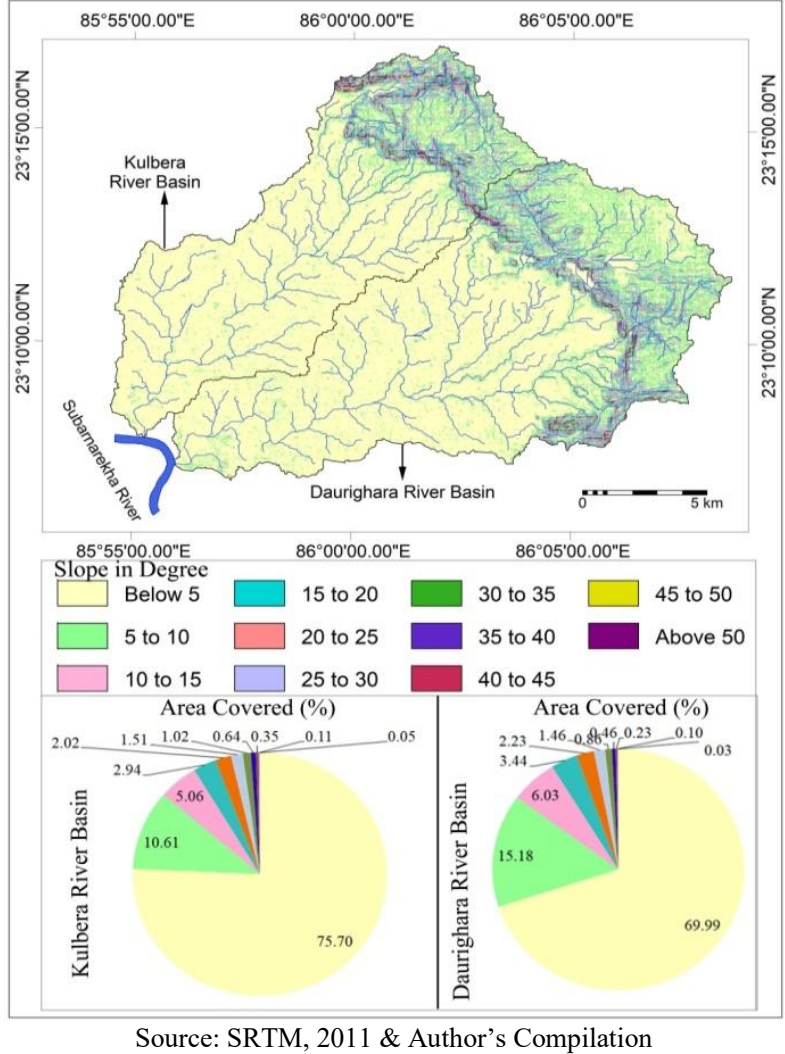

Fig. 4. Slope Distribution of the Study Area

\section{Drainage Density}

According to Strahler, drainage density is shown by $\mathrm{Dd}=\mathrm{L} / \mathrm{A}$, where, $\mathrm{L}$ is the stream length in the watershed and A is the area of the watershed [18]. Figure 5 and table 2 shows the drainage density distribution zones of the study area. Drainage density has been classified into very high $(>4$ $\mathrm{km} / \mathrm{sq} . \mathrm{km}$.), high (3 to $4 \mathrm{~km} / \mathrm{sq} . \mathrm{km}$.), moderate (2 to 3 $\mathrm{km} . / \mathrm{sq} . \mathrm{km}$.), low (1 to $20 \mathrm{~km} . / \mathrm{sq} . \mathrm{km}$.) and very low ( $<1$ $\mathrm{km} . / \mathrm{sq} . \mathrm{km}$.). In the Kulbera basin, 52.36 percent area is under low drainage density zone (1 to $2 \mathrm{~km}$. stream length/sq.km.). 27.59 and 4.21 percent area are covered with moderate (2 to 3 $\mathrm{km}$. stream length/sq.km.) and high (3 to $4 \mathrm{~km}$. stream length/sq.km.) drainage density zones respectively and 0.21 percent area lies under very high $(>4 \mathrm{~km}$. stream length/sq.km.) drainage density. On the other hand, Daurighara river basin has been categorized into five classes like very low ( $<1 \mathrm{~km}$. stream length/sq.km.), low (1 to $2 \mathrm{~km}$. stream length/sq.km.), moderate (2 to $3 \mathrm{~km}$. stream length/sq.km.), high (3 to $4 \mathrm{~km}$. stream length/sq.km.) and very high ( $>4 \mathrm{~km}$. stream length/sq.km.). 18.89 percent area lies in very low drainage density zone. Low drainage density zone covers an area of 55.76 percent. Moderate and high drainage density zones cover an area of 23.83 percent and 1.43 percent respectively and 0.10 percent area is under very high drainage density of Daurighara river basin. Low drainage density area is poorly drained basin with a slow hydrological response from watershed making it highly susceptible to flooding, gully erosion etc. [19].

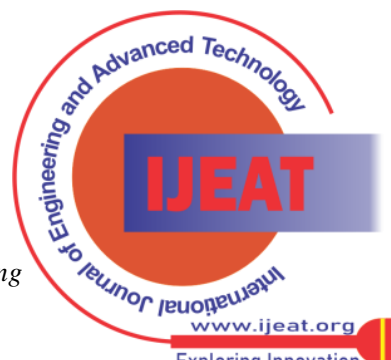


High drainage density area experience quick hydrological response to rainfall events and on the other hand, high drainage density area is characterized by impermeable subsoil material, sparse vegetation and high mountain relief [19].

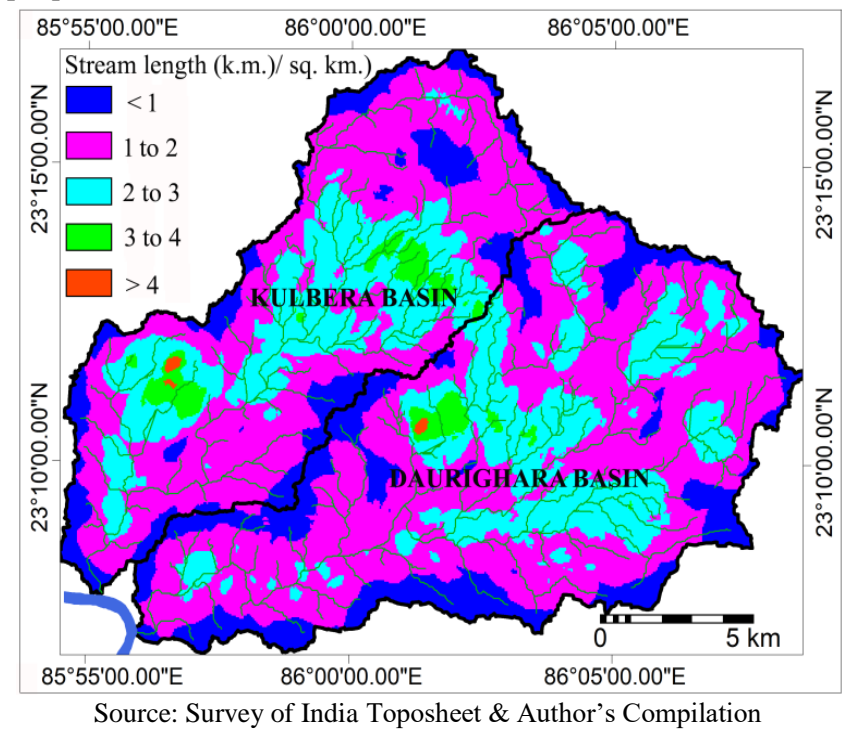

Fig. 5. Drainage Density of the Study Area

\begin{tabular}{|c|c|c|}
\hline \multirow{2}{*}{$\begin{array}{c}\text { Stream Length } \\
\text { km./sq. km. }\end{array}$} & \multicolumn{2}{|c|}{ Area covered in percent } \\
\cline { 2 - 3 } & Kulbera Basin & Daurighara Basin \\
\hline Below 1 & 15.62 & 18.89 \\
\hline 1 to 2 & 52.36 & 55.76 \\
\hline 2 to 3 & 27.59 & 23.83 \\
\hline 3 to 4 & 4.21 & 1.43 \\
\hline Above 4 & 0.21 & 0.10 \\
\hline
\end{tabular}

Table-II :Drainage Density Distribution of the Study Area

\section{E. River Channel Profile}

The length of Kulbera river channel is 36.6 kilometer and the elevation in the source and the mouth are 543.6 meter and 185 meter respectively. Valley length of kulbera river channel is 34.0 kilometer. Sinuosity of this channel is 1.08 [20]. Height difference between source and end point of Kulbera river channel is 358.6 meter and its gradient and slope are 1:102 and $0^{0} 33^{\prime} 40^{\prime \prime}$. On the other hand, length of the Daurighara river channel is 37.0 kilometer and valley length is 34.7 kilometer. So, sinuosity of this channel is 1.07. Elevation in source and end point of this channel are 587.6 meter and 180.5 meter respectively. Height difference between source and end point of Daurighara river channel are 407.1 meter. So, gradient and slope of this channel are 1: 91 and $0^{0} 37^{\prime} 49^{\prime \prime}$. Comparatively Daurighara river channel is steep than Kulbera river channel. Figure 6 shows the longitudinal channel profile of both the river channels.
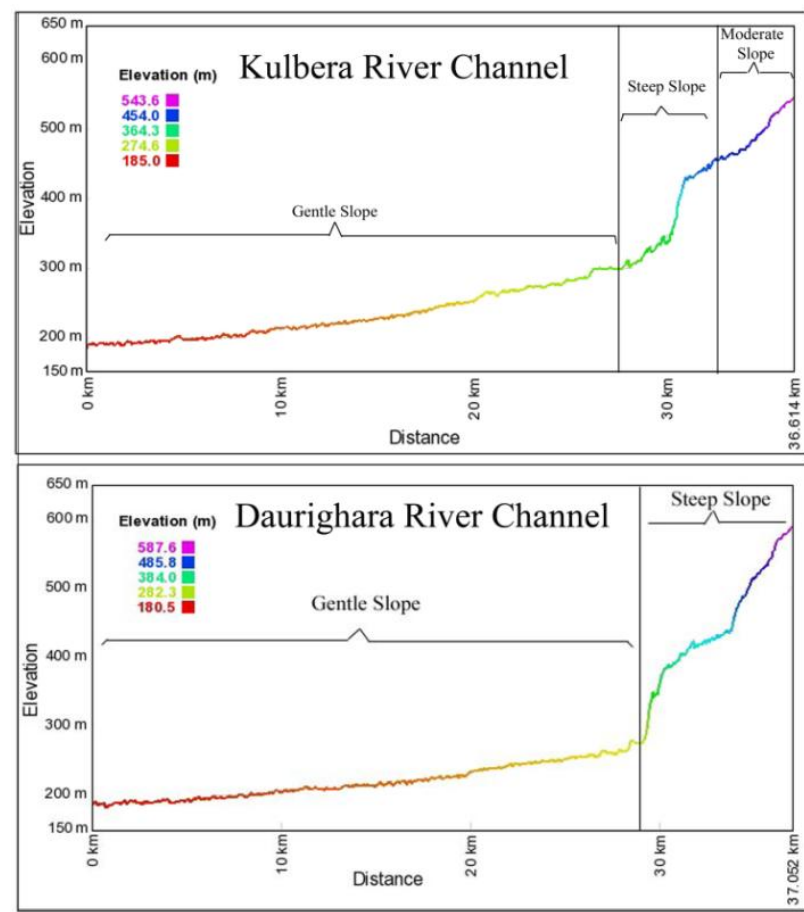

Source: www.gpsvisualizer.com \& Author's Compilation

Fig. 6. Longitudinal Channel Profile

\section{MORPHOMETRIC ANALYSIS}

Morphometry analyzed the shape and dimensions of the landforms and it is considered as an effective mathematical approach to describe the geomorphic condition and hydrological processes of the basin. The basic parameters which have taken for the investigation of basin morphometry consist of area, altitude, volume, slope profile and texture of landforms. The GIS technique has been implemented to the different morphometric parameters to link the drainage morphometry and landforms properties [21]. Different sub watershed represents relative morphometric characteristics with respect to the hydrological response of the watershed [22]. The main aim of the study is to discover the comparative stream properties by the measurement and computation of its various parameters. Comparative morphometric parameters of Kulbera and Daurighara watersheds were studied results are given below (Table-Stream order). Comparative quantitative morphometric characteristics of drainage network, basin geometry, drainage texture, relief aspects, and areal aspects of both river basins are given in the table $4 \& 5$. The morphometric analysis of the watersheds was carried out from the Survey of India topographical maps no. 73E/15, 73E/16, 73I/3 and 73I/4 on the scale 1:50,000 and SRTM (DEM) with 30 meter spatial resolution. The linear aspects were studied using the methods of Horton (1945), Strahler (1953), Chorley (1957), the areal aspects using methods of Schumm (1956), Strahler (1956 \& 1968), Miller (1953) and Horton (1932) and the relief aspects using the techniques of Horton (1945), Broscoe (1959), Melton (1957), Schumm (1954) , Strahler (1952) and (2004).

Pareta

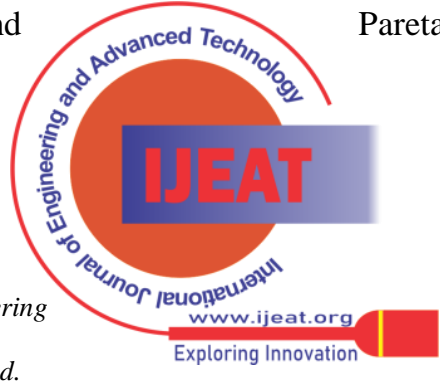




\section{A. Drainage Network Analysis}

\section{a. Stream Order (Su)}

Strahler' stream ordering is the first step to be performed for the quantitative analysis of the watershed. There are four different types of stream ordering system such as Gravelius, 1914; Horton, 1945; Strahler, 1952; Schiddeggar, 1970. The stream ordering systems was first promoted by Horton (1945) but Strahler (1952) make some modification of this ordering system [2-3]. Stream ordering of Kulbera and Daurighara watersheds were calculated based on Strahler's scheme (1964). Kulbera watershed has $4^{\text {th }}$ order main channel and Daurighara watershed has $6^{\text {th }}$ order main channel (Figure 7). Total numbers of stream segments of Kulbera and Daurighara watersheds are 272 and 366 and it was found that stream frequency decreases with increasing stream order.

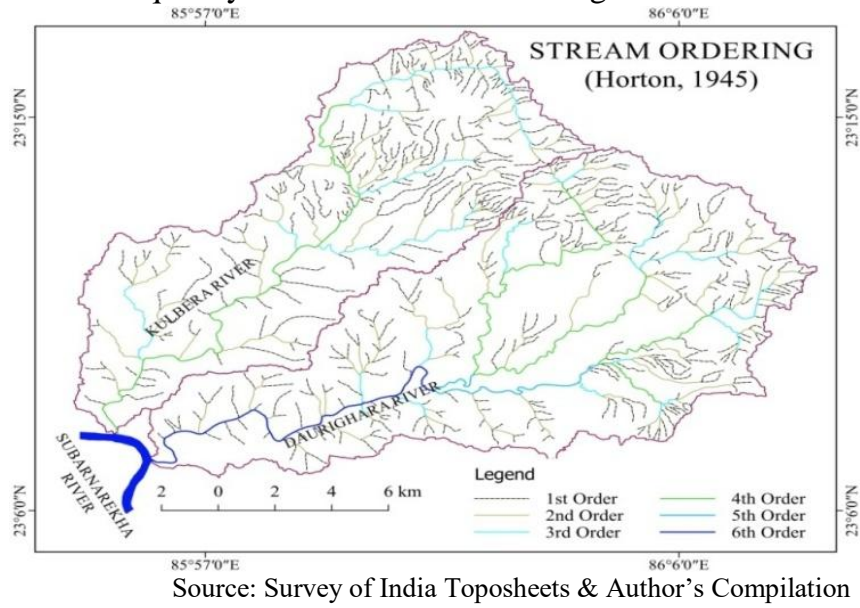

Fig. 7. Stream Ordering of the Study Area

\section{b. Stream Number $(\mathrm{Nu})$}

Stream number is defined the order wise total stream segments. The number of stream segment of each order form an inverse geometric sequence with order number [23]. Generally, number of streams gradually decreases with increasing stream order. Stream order variation and size of tributary depends on physiographical, geomorphological and structural characteristics of the basin. Total numbers of stream segments of Kulbera and Daurighara river basins have been identified 272 and 366 which have $4^{\text {th }}$ order and $6^{\text {th }}$ order stream (Figure). The higher amount of first order stream indicates the higher intensity of permeability and infiltration [24]. Kulbera river basin has 217 number of first order, 47 number of second order and 7 number of third order stream. On the other hand Daurighara river basin has 276 number of first order, 68 number of second order, 15 number of third order, 4 number of fourth order, 2 number of fifth order stream (Table 3).

\section{c. Stream Length $(\mathrm{Lu})$}

Stream length has been calculated on the basis of Horton's law and it is most important morphometric parameter for giving us about surface runoff hydrological characteristics of the area. Steep slopes and better textures represent small length of river of a region and river having longer lengths are commonly suggestive of smoother slope. Number of streams of various orders has been counted and stream lengths have been measured from source to mouth of both river basins with the help of MapInfo 10.0 GIS software. Total stream

length of Kulbera and Daurighara river basins are 254.5 kilometer and 319 kilometer respectively.

\section{d. Mean Stream Length (Lsm)}

Mean stream length is a dimensionless property revealing the characteristic size of components of a drainage network and its contributing watershed surface [9]. It is calculated by dividing length of streams of an order by total number of stream segments of that order. Stream length ratio is the ratio of the mean $(\mathrm{Lu})$ of stream segments of an order to mean length segments of the next lower order (Lu-1), which is constant throughout the successive orders of a basin [11, 23, 25]. Mean stream length has been calculated based on the method proposed by Strahler (1964). Order wise mean stream length of Kulbera river basin ranges from $0.69 \mathrm{~km}$. to 22.5 $\mathrm{km}$. and Daurighara river basin varies from $0.61 \mathrm{~km}$. to 14.0 $\mathrm{km}$. Calculation of mean stream length and stream length ratio of both watershed are shown in table 3 .

\section{e. Bifurcation Ratio (Rb)}

The bifurcation ratio is the ratio of the number of stream segments of given order $(\mathrm{Nu})$ to the numbers of stream segments in the next higher order $(\mathrm{Nu}+1)$ (Table 3). According to Horton (1945), bifurcation ratio is the index of relief and dissection. Strahler (1954) states that bifurcation ratio displays a small range of variation for different regions or different environment except where the powerful geological control dominates. It is seen that bifurcation ratio is not same from one order to next higher order. These irregularities are dependent upon the geological and lithological development of the watershed [9]. The bifurcation ratio generally varies from 3.0 to 5.0. The lower value of bifurcation ratio indicates less structural disturbances and their drainage pattern has not been distorted due to geological and structural rocks of the watershed [26-27, 15, 28]. The bifurcation ratio of Kulbera and Daurighara river basin varies from 4.62 to 7.0 and 2.0 to 4.53 respectively (Table 3 ).

\section{f. Weighted Mean Bifurcation Ratio (Rbwm)}

Strahler (1953) used a more representative bifurcation number as known as weighted mean bifurcation ratio. It is obtained by multiplying of each successive pair of orders by the total number of streams involved in the ratio and taking the mean of the sum of these values. Weighted mean bifurcation ratio of Kulbera and Daurighara river basins are 5.02 and 4.09 respectively (Table). Drainage pattern of Daurighara river basin is less structural disturbance compare to drainage pattern of Kulbera river basin.

\section{g. Rho Coefficient (p)}

The Rho coefficient is the ratio of stream length ratio and bifurcation ratio [23] and it is an important morphometry parameter relating drainage density to physiographic development of a watershed. Rho value has been changed with changing climate, geology, biology, geomorphology and anthropology.

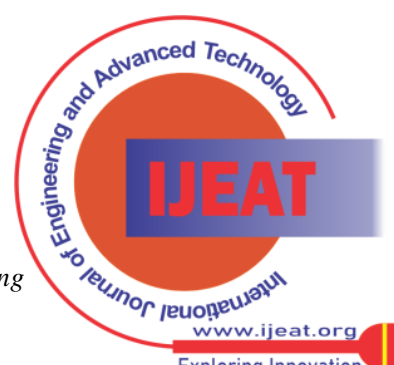


Rho values of Kulbera and Daurighara river basin are 0.58 and 0.71 respectively. Daurighara river basin is higher hydrologic storage during floods compare to Kulbera river basin.

\section{Table-III : Morphometric Parameters of Kulbera and} Daurighara Watersheds

\begin{tabular}{|c|c|c|c|c|c|c|c|c|c|c|}
\hline \multirow{6}{*}{ 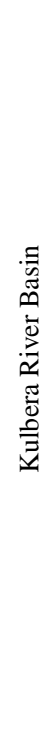 } & $\mathrm{Su}$ & $\bar{z}$ & 3 & $\vec{\sim}$ & वै & 妾 & $\begin{array}{l}\stackrel{5}{3} \\
\stackrel{*}{*} \\
\text { مै }\end{array}$ & 点 & 䍐 & $\frac{1}{2}$ \\
\hline & I & $\hat{}$ & 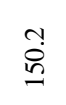 & 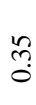 & $\underset{\leftarrow}{\widetilde{\leftarrow}}$ & ఫ్ & $\begin{array}{l}\infty \\
0 \\
\stackrel{D}{~} \\
\stackrel{\beth}{\beth}\end{array}$ & : & 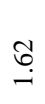 & \multirow{5}{*}{ ชิ } \\
\hline & II & f & $\begin{array}{l}\text { ஸे } \\
\text { గ̂. }\end{array}$ & 贵 & $\sqrt{\widehat{\theta}}$ & H & $\begin{array}{l}\text { ले } \\
\text { ֶָల్ల }\end{array}$ & $\underset{7}{ت}$ & $\underset{\hat{n}}{\stackrel{N}{N}}$ & \\
\hline & III & $\wedge$ & $\overrightarrow{\mathrm{N}} \wedge$ & $\begin{array}{l}\stackrel{0}{0} \\
\hat{o}\end{array}$ & $n$ & $\infty$ & เొ & 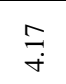 & تे & \\
\hline & IV & -1 & 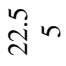 & ' & ' & ' & ' & IR & ' & \\
\hline & Total & $\stackrel{N}{N}$ & 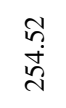 & : & 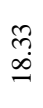 & $\underset{\sim}{\mathscr{N}}$ & $\begin{array}{l}\widetilde{\sigma} \\
\infty \\
0 \\
0 \\
\sigma\end{array}$ & $\begin{array}{l}30 \\
10 \\
\infty \\
\sim\end{array}$ & $\begin{array}{l}\stackrel{1}{\hat{0}} \\
\stackrel{0}{0}\end{array}$ & \\
\hline \multirow{7}{*}{ 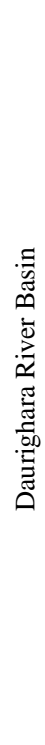 } & I & 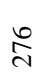 & 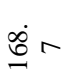 & 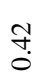 & $\underset{+}{\mathscr{+}}$ & $\underset{m}{\sharp}$ & & $\stackrel{\sigma}{0}$ & $\underset{i}{\mathbb{N}}$ & \multirow{7}{*}{$\stackrel{\mathscr{P}}{+}$} \\
\hline & II & 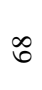 & $\stackrel{\text { ले }}{\stackrel{\nabla}{ }}$ & 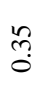 & 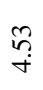 & $\infty$ & $\begin{array}{l}\stackrel{a}{\alpha} \sigma \\
\text { Li }\end{array}$ & $\stackrel{\text { L }}{\circ}$ & : & \\
\hline & III & $\stackrel{2}{\sim}$ & 龒 & 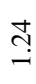 & $\begin{array}{l}\stackrel{L}{\hat{N}} \\
\dot{n}\end{array}$ & 9 & 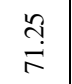 & . & $\underset{\stackrel{J}{+}}{\stackrel{J}{*}}$ & \\
\hline & IV & $\nabla$ & $\begin{array}{l}\stackrel{8}{0} \\
\text { ले }\end{array}$ & సิ & $N$ & 0 & $\approx$ & $\stackrel{\widehat{\curvearrowright}}{\wedge}$ & นึ. & \\
\hline & V & $N$ & $\begin{array}{l}\infty \\
\vec{\sigma} \\
\sigma\end{array}$ & นึ & $N$ & $m$ & 0 & 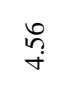 & $\stackrel{\hat{m}}{\dot{m}}$ & \\
\hline & VI & -1 & $\Xi$ & ' & ' & ' & 1 & $\stackrel{\circ}{\underset{\sim}{ \pm}} 0$ & ' & \\
\hline & Total & d্ & $\begin{array}{l}\text { Fे } \\
\text { ने }\end{array}$ & $\begin{array}{l}\infty \\
\infty \\
\dot{m}\end{array}$ & $\begin{array}{l}\text { m. } \\
\text { ف }\end{array}$ & 㤏 & 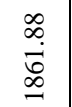 & $\begin{array}{l}\hat{0} \\
\stackrel{N}{ }\end{array}$ & $\begin{array}{l}\vec{b} \\
\exists \\
=\end{array}$ & \\
\hline
\end{tabular}

Su: Stream order, Nu: Number of streams, Lu: Stream length, RL: Stream length ratio $(\mathrm{RL}=\mathrm{Lu} / \mathrm{Lu}-1)$, Rb: Bifurcation ratios, Nu-r: Number of stream used in the ratios, Lsm: Mean stream length, Lurm: Mean stream length ratio, Rbwm: Weighted mean bifurcation ratios.

\section{B. BASIN GEOMETRY}

\section{a. Basin Area (A)}

The length of the stream depends on the area of the watershed and it is very important parameter in morphometry analysis. According to Schumm (1956), there are interesting relation between the total watershed areas and the total stream lengths which are supported by the water contributing areas. Author has calculated the basin area using ILWIS 3.0 software. The area of Kulbera and Daurighara river basins are 118.50 sq. km. and 160.04 sq. km. respectively (Table 4).

\section{b. Basin Parameter (P)}

Basin perimeter is an important parameter that determines the outer boundary of the watershed. It is identified along the watersheds and may be used as an indicator of size and shape of the watershed. In this study, basin perimeters of Kulbera and Daurighara watersheds are 70.72 kilometer and 77.92 kilometer respectively (Table 4).

\section{c. Length of the basin ( $L b)$}

According to Schumm (1956), the length of the basin is the longest dimension of the basin parallel to the main drainage line. Gregory defined the basin as the longest length of the basin in which one end being the mouth. As per Gardiner (1975), the basin length is the length of the line of a basin from the mouth to a point on the perimeter equidistant from the basin outlet in either direction. Length of Kulbera and Daurighara river basin have been determined approximately 20.7 kilometer and 23.04 kilometer respectively (Table 4).

\section{d. Length of Main Channel (Cl)}

Main channel length is the longest watercourse from the outflow of the designated watershed to the upper limit of the watershed boundary [25]. Length of main channel has been calculated using ILWIS 3.o GIS software. Main channel lengths of Kulbera and Daurighara river basins are $36.6 \mathrm{~km}$. and $37.0 \mathrm{~km}$. respectively (Table).

\section{e. Length Area Relation (Lar)}

According to Hack (1957) for a large number of basins, the stream length and basin area is associated by a simple power function as follows: $\operatorname{Lar}=1.4 * \mathrm{~A}^{0.6}[25,21]$. Lar value of Kulbera and Daurighara river basins are 24.7 and 29.42 respectively (Table 4).

\section{f. Lemniscate's $(K)$}

Chorely (1957) uses the Lemniscate's value to compute the slope of the basin. In the formula $\mathrm{K}=\mathrm{Lb}^{2} / \mathrm{A}$ where, $\mathrm{Lb}$ is the basin length in kilometer and $\mathrm{A}$ is the area of the basin in square kilometer. The Lemnisate's value of Kulbera basin is 3.62 and 3.32 for Daurighara basin (Table 4) which shows the watershed area occupies maximum area with large number of higher order streams.

\section{g. Form Factor (Ff)}

According to Horton (1932) form factor is defined as the ratio of area of basin to square of the basin length and it varies from 0 to 1 but may always be less than 0.754 ( 1 for a perfectly circular watershed). Lower value indicates the elongated shape with longer duration flow other hand higher value represents circular shape with high peak flows of shorter duration. In the study area, form factor value of Kulbera and Daurighara river basins are 0.28 and 0.30 respectively (Table 4). Kulbera basin is little elongated than Daurighara basin.

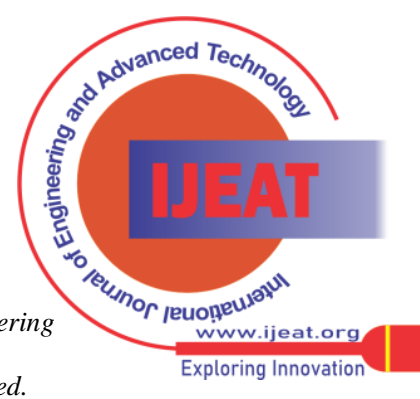




\section{h. Elongation Ratio (Re)}

Schumm (1956) defined elongation ratio as the ratio of a diameter of circle of the some area of the basin to the maximum basin length. According to Strahler (1952) elongation ratio varies from 0.6 to 1.0 with variation of climate and geological types. Slopes of watershed variation may be categorized with the help of elongation ratio index i.e., circular ( 0.90 to 1.0$)$, oval ( 0.8 to 0.9$)$, less elongated $(0.7$ to 0.8 ), elongated ( 0.5 to 0.7$)$, and more elongated $(<0.5)$ for tectonically high active, active, slightly active and inactive respectively [29]. The elongation ratio of Kulbera river basin is 0.02 which represents more elongated and Daurighara river basin 0.01 which indicates more elongated with longer duration flow compare to Daurighara basin.

\section{i. Texture Ratio (Rt)}

Texture ratio is defined as the ratio between the first order stream and perimeter of the basin i.e. Rt $=\mathrm{N}_{1} / \mathrm{P}$ and the under laying lithology, infiltration capacity and relief aspect of topography have determined the texture ratio [2-3, 42]. Texture ratio is an important factor in drainage morphometry analysis and it indicates the groundwater recharge capacity of the watershed. Texture ratio of Kulbera river basin is 3.07 and 3.54 for Daurighara river basin (Table). Both drainage basins have similar characteristics in nature.

\section{j. Circulatory Ratio $(R c)$}

Strahler (1964) and Miller (1953) have used circulatory ratio as a quantitative method for morphometry analysis. Circulatory ratio is the ratio of watershed area to the area of circular having some perimeter as the watershed and it represents the lithological character of watershed. According to miller (1953) circulatory ratio ranges from 0.40 to 0.50 which indicates strongly elongated and highly permeable homogeneous geologic materials [21, 25, 42]. The circulatory ratio value of Kulbera basin is 0.30 and 0.33 is for Daurighara basin. It indicates that both watersheds are less elongated, moderate discharge of rainfall and permeability of subsoil condition. Sub surface permeability of Daurighara watershed is higher than Kulbera watershed.

\section{k. Compactness Coefficient (Cc)}

Grevelius (1914) defined the compactness coefficient as the ratio of perimeter of watershed circumference of circular area which equals the same area of the watershed. It is dependent on the slope. In case of circular basin, the drainage is more hazardous while it yields the shortest time of concentration before the peak flow occurrence [31, 30]. The lesser value of compactness coefficient is more prone to erosion. Compactness coefficient of Kulbera basin is1.85 and 1.75 is for Daurighara basin (Table 4). Daurighara basin is more erosion than Kulbera basin.

\section{l. Fitness Ration (Rf)}

Melton (1957) defined fitness ratio as the main channel length to the perimeter of watershed. It is a measure of topographical fitness. Fitness ratio value is 0.51 for Kulbera watershed and 0.47 for Darighara watershed (Table 4).

\section{m. Wandering Ratio (Rw)}

According to Smart and Surkan (1967), the wandering ratio is the ratio of the main channel length and the valley length. Valley length is the straight line distance from outlet of the basin and the farthest point on the ridge of the watershed [25, 21]. The wandering ratio of Kulbera basin is 1.77 and 1.58 is for Daurighara basin (Table 4).

n. Watershed Eccentricity (T)

According to Black (1972) watershed eccentricity equation is

defined as follows

$\mathrm{T}=\frac{\left[\left(L c m^{2}-W c m^{2}\right)\right]^{\wedge} 0.5}{W C M}$

Where, $\quad \mathrm{T}=$ Watershed eccentricity.

$\mathrm{Lcm}=$ Straight line distance from the watershed mouth to the ridge of the watershed through centre of the mass.

$\mathrm{Wcm}=$ Width of the watershed which perpendicular to $\mathrm{Lcm}$ at the centre of the mass.

Watershed eccentricity represents the shape of the watershed to an ellipse for which the major axis is twice the minor axis. Watershed eccentricity of Kulbera river basin is 2.72 and Daurighara river basin is 2.48 (Table).

\section{o. Sinuosity Index (Si)}

Sinuosity index represents the pattern of channel of a drainage basin. Sinuosity is the ratio of channel length and valley length. It ranges from 1 to 4 or more. It has been categorized that river's nature like straight having $\mathrm{SI}<1.05$, small meandering $\mathrm{SI}=1.05$ to 1.3 , moderate meandering $\mathrm{SI}=$ 1.3 to 1.5 and meandering $>1.5$ [33]. Sinuosity index has been calculated by using Mueller (1968) theory and 1.08 sinuosity indexes have been found for Kulbera basin and 1.06 for Daurighara basin (Table 4). Sinuosity of both basins varies from 1.05 to 1.30 having small meandering.

\section{p. Channel Index (Ci) and Valley Index (Vi)}

Mueller (1968) suggested that the river channel has been number of segments for determination of sinuosity parameter. Channel length, length of valley and shortest distance from source to the outlet (Air distance) are required for computation of channel and valley index of the watershed. Channel index of Kulbera and Daurighara basin are 1.80 and 1.83 respectively. 1.67 and 1.72 are valley index of Kulbera and Daurighara river basin (Table 4). Geomorphologist, Hydrologist and Geologist have used the sinuosity index for interpreting the significance of streams in the evaluation of landscapes. According to Mueller (1968), topographic and hydraulic and sinuosity index are the important computation for the flow of natural stream courses and the development of floodplains. Hydraulic, topographic and sinuosity index have been computed. Topographic index of Kulbera and Daurighara basins are 119.4 percent and 115.27 percent respectively (Table 4) and Hydraulic index of Kulbera and Daurighara basin are16.25 percent and 13.25 percent respectively (Table 4).

Published By:

Blue Eyes Intelligence Engineering and Sciences Publication

(C) Copyright: All rights reserved.

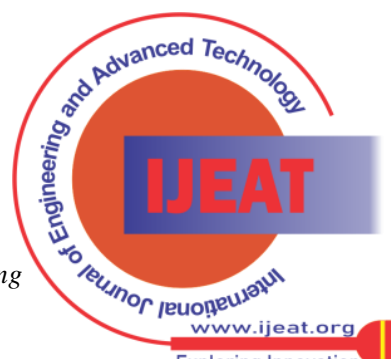


Table-IV : Basin Geometry of Kulbera and Daurighara Watersheds

\begin{tabular}{|c|c|c|c|c|}
\hline $\begin{array}{l}\text { Stream } \\
\text { Property }\end{array}$ & $\begin{array}{l}\text { Formula/ } \\
\text { Method }\end{array}$ & References & $\begin{array}{c}\text { Kulber } \\
\text { a River } \\
\text { Basin }\end{array}$ & $\begin{array}{c}\text { Daurighar } \\
\text { a River } \\
\text { Basin }\end{array}$ \\
\hline $\begin{array}{l}\text { Basin Length } \\
\text { (Lb) in kms. }\end{array}$ & GIS Software & $\begin{array}{l}\text { Schumm } \\
\text { (1956) }\end{array}$ & 20.7 & 23.04 \\
\hline $\begin{array}{l}\text { Basin Width } \\
\text { (W) in kms. }\end{array}$ & GIS Software & $\begin{array}{l}\text { Schumm } \\
\text { (1956) }\end{array}$ & 7.15 & 8.6 \\
\hline $\begin{array}{l}\text { Mean Basin } \\
\text { Width (Wb) in } \\
\text { kms. }\end{array}$ & GIS Software & $\begin{array}{l}\text { Schumm } \\
\text { (1956) }\end{array}$ & 6.57 & 6.89 \\
\hline $\begin{array}{l}\text { Basin Perimetre } \\
\text { (P) in kms. }\end{array}$ & GIS Software & $\begin{array}{l}\text { Schumm } \\
\text { (1956) }\end{array}$ & 70.72 & 77.92 \\
\hline $\begin{array}{l}\text { Basin Area (A) } \\
\text { in sq. kms }\end{array}$ & GIS Software & $\begin{array}{l}\text { Schumm } \\
\text { (1956) }\end{array}$ & 118.5 & 160.04 \\
\hline $\begin{array}{l}\text { Relative } \\
\text { Parametre (Pr) }\end{array}$ & $\mathrm{Pr}=\mathrm{A} / \mathrm{P}$ & $\begin{array}{l}\text { Schumm } \\
\text { (1956) }\end{array}$ & 1.68 & 2.05 \\
\hline $\begin{array}{l}\text { Length Area } \\
\text { Relation (Lar) }\end{array}$ & $\mathrm{Lar}=1.4^{*}(\mathrm{~A})^{0.6}$ & Hack (1957) & 24.57 & 29.42 \\
\hline $\begin{array}{l}\text { Lemniscate's } \\
\text { (k) }\end{array}$ & $\mathrm{k}=(\mathrm{Lb})^{2} / \mathrm{A}$ & $\begin{array}{l}\text { Chorely } \\
\text { (1957) }\end{array}$ & 3.62 & 3.32 \\
\hline $\begin{array}{l}\text { Form Factor } \\
\text { Ratio (Ff) }\end{array}$ & $\mathrm{Ff}=\mathrm{A} /(\mathrm{Lb})^{2}$ & $\begin{array}{l}\text { Horton } \\
(1932)\end{array}$ & 0.28 & 0.3 \\
\hline $\begin{array}{l}\text { Shape Factor } \\
\text { Ratio Sf) }\end{array}$ & $\mathrm{Sf}=(\mathrm{Lb})^{2} / \mathrm{A}$ & $\begin{array}{l}\text { Horton } \\
(1932) \\
\end{array}$ & 3.62 & 3.32 \\
\hline $\begin{array}{l}\text { Elongation } \\
\text { Ration (Re) }\end{array}$ & $\begin{array}{c}\mathrm{Re}=2 / \mathrm{Lb} \\
)^{0.5}\end{array}$ & $\begin{array}{l}\text { Schumm } \\
\text { (1956) }\end{array}$ & 0.02 & 0.01 \\
\hline $\begin{array}{l}\text { Circulatory } \\
\text { Ratio (Rc) } \\
\end{array}$ & $\begin{array}{c}\mathrm{Rc}=12.57 *(\mathrm{~A} / \\
\left.\mathrm{P}^{2}\right)\end{array}$ & Miller (1960) & 0.3 & 0.33 \\
\hline $\begin{array}{l}\text { Compactness } \\
\text { Coefficient } \\
\text { (Cc) }\end{array}$ & $\begin{array}{c}\mathrm{Cc}=0.2841 * \mathrm{P} / \\
\mathrm{A}^{0.5}\end{array}$ & $\begin{array}{l}\text { Gravelius } \\
\text { (1914) }\end{array}$ & 1.85 & 1.75 \\
\hline $\begin{array}{l}\text { Fitness Ratio } \\
\text { (Rf) }\end{array}$ & $\mathrm{Rf}=\mathrm{Cl} / \mathrm{P}$ & $\begin{array}{l}\text { Melton } \\
(1957) \\
\end{array}$ & 0.51 & 0.47 \\
\hline $\begin{array}{l}\text { Wandering } \\
\text { Ratio (Rw) }\end{array}$ & $\mathrm{Rw}=\mathrm{Cl} / \mathrm{Lb}$ & $\begin{array}{c}\text { Smart \& } \\
\text { Surkan } \\
(1967)\end{array}$ & 1.77 & 1.58 \\
\hline $\begin{array}{l}\text { Watershed } \\
\text { Eccenticity (T) }\end{array}$ & $\begin{array}{c}\mathrm{T}=\left(\left(\mathrm{Lb}^{2}-\mathrm{W}^{2}\right)^{0 .}\right. \\
5) / \mathrm{W}\end{array}$ & Black (1972) & 2.72 & 2.48 \\
\hline $\begin{array}{l}\text { Down Vally } \\
\text { distance (Vd) }\end{array}$ & GIS Software & $\begin{array}{l}\text { Mueller } \\
\text { (1968) }\end{array}$ & $\begin{array}{c}22.55 \\
\text { (4th } \\
\text { order } \\
\text { stream } \\
\text { length) }\end{array}$ & $\begin{array}{c}14.40 \text { (6th } \\
\text { order } \\
\text { stream } \\
\text { length) }\end{array}$ \\
\hline $\begin{array}{l}\text { Main Channel } \\
\text { Length }(\mathrm{Cl}) \text { in } \\
\text { kms }\end{array}$ & GIS Software & - & 36.6 & 37 \\
\hline $\begin{array}{l}\text { Valley Length } \\
\text { (Vl) in kms }\end{array}$ & GIS Software & - & 34 & 34.7 \\
\hline $\begin{array}{l}\text { Minimum } \\
\text { Aerial Distance } \\
(\mathrm{ADM}) \text { in kms. }\end{array}$ & GIS Software & - & 20.38 & 20.17 \\
\hline $\begin{array}{l}\text { Channel Index } \\
\text { (Ci) }\end{array}$ & $\begin{array}{c}\mathrm{Ci}=\mathrm{Cl} / \mathrm{ADM} \\
(\mathrm{H} \& \mathrm{TS})\end{array}$ & $\begin{array}{c}\text { Mueller } \\
\text { (1968) }\end{array}$ & 1.8 & 1.83 \\
\hline $\begin{array}{l}\text { Valley Index } \\
\text { (Vi) }\end{array}$ & $\begin{array}{c}\mathrm{Vi}=\mathrm{Vl} / \mathrm{ADM} \\
(\mathrm{TS})\end{array}$ & $\begin{array}{c}\text { Mueller } \\
(1968)\end{array}$ & 1.67 & 1.72 \\
\hline $\begin{array}{l}\text { Standard } \\
\text { Sinuosity Index } \\
\text { (Ssi) }\end{array}$ & $\mathrm{Ssi}=\mathrm{Ci} / \mathrm{Vi}$ & $\begin{array}{l}\text { Mueller } \\
\text { (1968) }\end{array}$ & 1.08 & 1.06 \\
\hline $\begin{array}{l}\text { Hydraulic } \\
\text { Sinuosity (Hsi) } \\
\%\end{array}$ & $\begin{array}{c}\mathrm{His}=((\mathrm{Ci}-\mathrm{Vi}) /( \\
\mathrm{Ci}-1))^{*} 100\end{array}$ & $\begin{array}{l}\text { Horton } \\
(1945)\end{array}$ & 16.25 & 13.25 \\
\hline $\begin{array}{l}\text { Topographic } \\
\text { Sinuosity Index } \\
\text { (Tsi) \% }\end{array}$ & $\begin{array}{c}\text { Tsi }=((\mathrm{Vi}-1) /(\mathrm{C} \\
\mathrm{i}-1)) * 100\end{array}$ & $\begin{array}{l}\text { Schumm } \\
\text { (1965) }\end{array}$ & 119.4 & 115.27 \\
\hline $\begin{array}{l}\text { Length of } \\
\text { Overland Flow } \\
\text { (Lg) in kms. }\end{array}$ & $\mathrm{Lg}=(\mathrm{A} / 2)^{*} \mathrm{Lu}$ & $\begin{array}{l}\text { Horton } \\
(1945)\end{array}$ & 0.23 & 0.25 \\
\hline $\begin{array}{l}\text { Texture Ratio } \\
\text { (Rt) }\end{array}$ & $\mathrm{Rt}=\mathrm{N} 1 / \mathrm{P}$ & $\begin{array}{c}\text { Schumm } \\
\text { (1965) }\end{array}$ & 3.07 & 3.54 \\
\hline
\end{tabular}

Source: Author's Compilation

\section{Drainage Texture Analysis \\ a. Stream Frequency (Fs)}

Horton (1932) introduced the drainage frequency that means stream frequency. It is the number of stream segments per unit area. In the present study, the stream frequency of Kulbera and Daurighara river basins are 2.29 (Table 5). Higher stream frequency indicates the larger surface runoff, steeper ground surface, impermeable surface, sparse vegetation, and high relief condition. Low stream frequency indicates high permeable geology and low relief. Higher stream frequencies also indicate the early stage of the fluvial cycle or rejuvenated erosional activities [34].

\section{b. Drainage Density (Dd)}

Drainage density is the length of all stream order per unit basin area [23]. It indicates the landscape dissection index and runoff potential [35]. Drainage density shows the infiltration capacity and vegetation cover of the catchment area [36]. Drainage of water and sediment from the catchments are depended on drainage density [37]. Groundwater potentiality of the catchment area depends on drainage density because it is related with surface runoff and permeability. Low drainage density represents the permeable subsoil material, dense vegetation and low relief [38]. High drainage density shows impermeable subsurface material, sparse vegetation and mountain relief. Low and high drainage density leads to coarse and fine drainage texture. The drainage density value of Kulbera and Daurighara river basins are 2.15 and 1.99 kilometer per square kilometer respectively (Table 5) which indicate gentle to steep slope terrain, medium dense vegetation and less permeable with medium rainfall.

\section{c. Drainage Texture (Dt)}

Drainage texture has measured the relative channel spacing in a fluvial dissected plateau and it is the product of drainage density and drainage frequency which is controlled by climate, rainfall, vegetation, lithology, soil type, infiltration capacity and stage of development [39]. Vegetation cover, type and density play an important role in determining the drainage texture [40]. Unprotected soft and weak rocks produce a fine texture where as massive and resistant rocks produce coarse texture. The texture of rock is commonly dependent upon vegetation and climate [41]. Horton (1945) stated that infiltration capacity is the single important factor which influences drainage texture and it includes drainage density and stream frequency. Drainage texture has been categorized into five different classes such as very coarse ( $<2)$, Coarse ( 2 to 4 ), Moderate ( 4 to 6 ), fine (6 to 8$)$ and very fine $(>8)$ [39, 42]. In the present study drainage texture of Kulbera and Daurighara river basins were found to be 3.85 and 4.7 respectively. Kulbera drainage basin has coarse drainage texture and moderate drainage texture has been found in Daurighara basin.

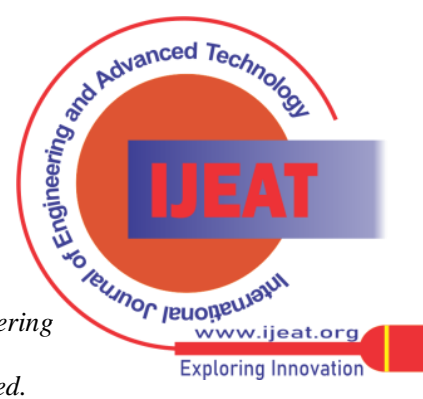




\section{d. Constant of Channel Maintenance (Cc)}

Constant of channel maintenance represents the requirement of units of watershed surface to bear one unit of channel length. According to Schumm (1956), Cc is the inverse of the drainage density having the dimension of length as a property termed constant of channel maintenance. Higher values of this parameter of the drainage basin represent lower value of drainage density. The calculated value of this parameter of Kulbera and Daurighara basins are 0.46 and 0.50 (Table 5). Higher value of constant of channel maintenance indicates strong control of lithology with a surface of high permeability and it also represents relatively higher infiltration rates, moderate surface runoff and less dissection. Watershed is not controlled by structural parameters.

\section{e. Drainage Intensity (Di)}

According to Faniran (1968), drainage intensity is the ratio of the stream frequency to the drainage density. In this study drainage intensity value of Kulbera basin 1.06 and 1.15 is found for Daurighara basin (Table 5). Lower value of drainage intensity represents little effect by the drainage density and stream frequency on the extent to which the surface has been lowered by agents of denudation. Having lower values of drainage density, stream frequency and drainage intensity are not quickly removed water from watershed causes high flooding, gully erosion and landslide.

\section{f. Infiltration Number (If)}

The infiltration number is the product of drainage density and stream frequency and it gives an idea about the infiltration characteristics of the watershed. The higher value of infiltration number indicates the lower infiltration and the higher surface runoff. Infiltration numbers of Kulbera and Daurighara watersheds are 4.92 and 4.55 respectively (Table 5).

\section{g. Drainage Pattern (Dp)}

Drainage pattern of the watershed reflects the influence of slope, lithology and structure. It helps us to identify the stage in the cycle of erosion. Drainage pattern shows some characteristics of the drainage basin through drainage pattern and drainage texture. It gives concept about the geology of the basin, the strike and dip of depositional rocks, existence of faults and other information about geological structures from the drainage pattern. According to Howard (1967) climate, permeability of rocks, vegetation and relief ratio etc. have controlled the drainage texture and it is related drainage pattern to geological information. Author has identified dendritic drainage pattern of both river basin. It indicates fairly homogeneous rock without control by the underlying geologic structure.

\section{h. Length of Overland Flow (Lg)}

Length of overland flow is the half of reciprocal of drainage density. It is the length of water flow over the ground surface before it is localized into main stream. Length of overland flow effects the hydrological and physiographic development of drainage basin 23]. When rainfall intensity exceeds soil infiltration capacity, the excess water flows over the land surface as overland flow [43]. Rock type, permeability, climate regime, vegetation cover, relief and
Published By:

Blue Eyes Intelligence Engineering and Sciences Publication

duration of erosion have controlled the overland flow [26]. Lower value of overland flow indicates low permeability, steep to very steep slopes and high surface runoff [44]. The computed values of overland flow are 0.23 and 0.25 for Kulbera and Daurighara basin respectively (Table 5).

Table-V : Drainage Texture of Kulbera and Daurighara Watershed

\begin{tabular}{|c|c|c|c|c|}
\hline $\begin{array}{l}\text { Stream } \\
\text { Property }\end{array}$ & $\begin{array}{l}\text { Formula } \\
\text { /Method }\end{array}$ & Refrences & $\begin{array}{c}\text { Kulbera } \\
\text { River } \\
\text { Basin } \\
\end{array}$ & $\begin{array}{c}\text { Daurighar } \\
\text { a River } \\
\text { Basin } \\
\end{array}$ \\
\hline $\begin{array}{l}\text { Drainage } \\
\text { Density } \\
(\mathrm{Dd}) \text { in } \\
\mathrm{km} / \mathrm{kms}^{2}\end{array}$ & $\begin{array}{c}\mathrm{Dd}=\mathrm{Lu} / \\
\mathrm{A}\end{array}$ & $\begin{array}{l}\text { Horton } \\
\text { (1932) }\end{array}$ & 2.15 & 1.99 \\
\hline $\begin{array}{c}\text { Drainage } \\
\text { Texture } \\
\text { (Dt) }\end{array}$ & $\begin{array}{c}\mathrm{Dt}=\mathrm{Nu} / \\
\mathrm{P}\end{array}$ & $\begin{array}{l}\text { Horton } \\
\text { (1945) }\end{array}$ & 3.85 & 4.7 \\
\hline $\begin{array}{l}\text { Stream } \\
\text { Frequenc } \\
\text { y (Fs) }\end{array}$ & $\begin{array}{c}\mathrm{Fs}=\mathrm{Nu} / \\
\mathrm{A}\end{array}$ & $\begin{array}{l}\text { Horton } \\
\text { (1932) }\end{array}$ & 2.29 & 2.29 \\
\hline $\begin{array}{l}\text { Length of } \\
\text { Overland } \\
\text { Flow (Lg) } \\
\text { in kms }\end{array}$ & $\begin{array}{c}\mathrm{Lg}=\mathrm{A} / 2 \\
{ }^{*} \mathrm{Lu}\end{array}$ & $\begin{array}{l}\text { Horton } \\
\text { (1945) }\end{array}$ & 0.23 & 0.25 \\
\hline $\begin{array}{l}\text { Infiltratio } \\
\text { n Number } \\
\text { (If) }\end{array}$ & $\begin{array}{c}\text { If }=\text { Fs } * D \\
\text { d }\end{array}$ & $\begin{array}{l}\text { Schumm } \\
\text { (1956) }\end{array}$ & 4.92 & 4.55 \\
\hline $\begin{array}{c}\text { Constant } \\
\text { of } \\
\text { Channel } \\
\text { Maintena } \\
\text { nce } \\
\left(\mathrm{kms}^{2} / \mathrm{km}\right. \\
\text { ) }\end{array}$ & $\mathrm{C}=1 / \mathrm{Dd}$ & $\begin{array}{l}\text { Schumm } \\
\text { (1956) }\end{array}$ & 0.46 & 0.5 \\
\hline $\begin{array}{l}\text { Drainage } \\
\text { Intensity } \\
\text { (Di) }\end{array}$ & $\begin{array}{c}\mathrm{Di}=\mathrm{Fs} / \\
\mathrm{Dd}\end{array}$ & $\begin{array}{c}\text { Faniran } \\
\text { (1968) }\end{array}$ & 1.06 & 1.15 \\
\hline $\begin{array}{l}\text { Drainage } \\
\text { Pattern }\end{array}$ & $\begin{array}{c}\text { GIS } \\
\text { Softwar } \\
\text { e }\end{array}$ & $\begin{array}{l}\text { Horton } \\
\text { (1932) }\end{array}$ & Dendritic & Dendritic \\
\hline
\end{tabular}

Source: Author's Compilation

\section{Relief Characteristics}

\section{a. Relief Ratio (Rhl)}

Difference between the elevation of highest point of the watershed and lowest elevation on the valley floor is known as basin relief. Relief ratio is the ratio of total relief of a basin to the longest dimension of the basin parallel with the main drainage line [23]. According to schumm (1956), it is a close relation with the hydrological characteristics of basins. He also found that sediments loose deposited per unit area are associated with the relief ratio. Lower values of relief ratio indicate the resistant basement rocks of the drainage basin and low degree of gradient [42]. It also represents the intensity of erosion progress operating on slopes of the basin [30]. Relief ratio values of Kulbera and Daurighara basins are 0.025 and 0.021 respectively (Table 6). 


\section{A Geospatial Morphometric Analysis of Kulbera and Daurighara River Basins in Western Part of Purulia District of West Bengal, India}

\section{b. Relative Relief (Rhp)}

The Maximum basin relief is defined the difference between highest elevation on the watershed perimeter and the lowest elevation on the mouth of stream of the watershed. Schumm (1956) was used basin relief for computation relief ratio. Author has used Melton's (1957) relative relief formula as given below.

$$
\begin{aligned}
& \text { Rhp }=\frac{\mathrm{H} * 100}{\mathrm{P}} \\
& \text { Where, } \quad \text { Rhp }=\text { Relative relief } \\
& \qquad \begin{aligned}
\mathrm{H} & =\text { Total basin relief in meter } \\
\mathrm{P} & =\text { Perimeter of the watershed in meter }
\end{aligned}
\end{aligned}
$$

Relative relief of Kulbera and Daurighara watersheds has been determined 726.81 meter and 607.03 meter respectively (Table 6).

\section{c. Absolute Relief (Ra)}

Absolute relief defined as the difference between elevation of the highest point of the watershed and sea level. Ra values of Kulbera and Daurighara watersheds are 646 meter and 601 meter respectively (Table 6).

\section{d. Channel Gradient $\mathrm{Cg}$ )}

The channel gradient is a fundamental parameter in the geomorphologic characteristics of river system. It is defined the total drops in elevation from source to the mouth in the river channel. It indicates the changes in the longitudinal sequence of river through the presence of waterfalls, step pools and riffle pools etc. Channel gradient of Kulbera and Daurighara basins were calculated to be 8.94 and 8.14 respectively (Table 6).

\section{e. Ruggedness Number (Rn)}

Ruggedness number is the combines of slope steepness and drainage length indicating the extent of the instability of land surface [45]. Rn value of Kulbera and Daurighara basins have been calculated and found to be 1.11 and 0.56 respectively (Table 6). Lower $\mathrm{Rn}$ value indicates less soil erosion prone area and has intrinsic structural complexity in association with relief and drainage density.

\section{f. Melton Ruggedness Number (MRn)}

Melton ruggedness number is a slope index that indicates the representation of relief ruggedness within the watershed [46]. Lower value of MRn indicates the normal flow in the main stream without more debris flow and higher value of MRn indicates rapid flow in the main stream with more debris in rugged hilly or mountain area. MRn value of Kulbera and Daurighara basins are 2.08 and 1.72 respectively (Table 6).

\section{g. Dissection Index (Dis)}

Dissection index is the ratio between actual dissection made by the rivers and highest elevation from the sea level of the area. It has determined the morphometry, physiographic attribute and magnitude of dissection of terrain [10]. Generally, Dissection values have varied from 0 to 1 (in exceptional case, vertical cliffs, it may be at vertical escarpment of hilly slope or at seashore). Lower value of dissection index implies old stage [47] of basin and less degree of dissection. Dis value of Kulbera and Daurighara basins are 0.80 and 0.79 respectively (Table 6).

\section{h. Gradient Ratio (Rg)}

Gradient ratio indicates the channel slope and it has assessed the runoff volume of the watershed [48]. Author has computed gradient ratio as given below formula.

$$
\begin{aligned}
& \mathrm{Rg}=\frac{(\text { Es }- \text { Em })}{\mathrm{Lb}} \\
& \text { Where, } \mathrm{Rg}=\text { Gradient ratio } \\
& \text { Es= Elevation at the source } \\
& \text { Em = Elevation at the mouth } \\
& \mathrm{Lb}=\text { Basin length }
\end{aligned}
$$

\begin{tabular}{|c|c|c|c|c|}
\hline $\begin{array}{c}\text { Relief } \\
\text { Property }\end{array}$ & Formula/Method & References & $\begin{array}{c}\text { Kulbera } \\
\text { River } \\
\text { Basin } \\
\end{array}$ & $\begin{array}{c}\text { Daurighara } \\
\text { River } \\
\text { Basin } \\
\end{array}$ \\
\hline $\begin{array}{l}\text { Maximum } \\
\text { Height of } \\
\text { the Basin in } \\
\text { Meter }(\mathrm{Z})\end{array}$ & GIS Software & - & 646 & 601 \\
\hline $\begin{array}{l}\text { Height of } \\
\text { Basin } \\
\text { Mouth in } \\
\text { Meter (z) }\end{array}$ & GIS Software & - & 132 & 128 \\
\hline $\begin{array}{l}\text { Total Basin } \\
\text { Relief }(\mathrm{H}) \\
\text { in Meter }\end{array}$ & $\mathrm{H}=\mathrm{Z}-\mathrm{z}$ & $\begin{array}{c}\text { Strahler } \\
\text { (1952) }\end{array}$ & 514 & 473 \\
\hline $\begin{array}{l}\text { Rilef Ratio } \\
\text { (Rhl) }\end{array}$ & $\mathrm{Rhl}=\mathrm{H} / \mathrm{Lb}$ & $\begin{array}{c}\text { Schumm } \\
\text { (1956) }\end{array}$ & 0.025 & 0.021 \\
\hline $\begin{array}{l}\text { Maximum } \\
\text { Relief (ZI) }\end{array}$ & GIS Software & & 646 & 601 \\
\hline $\begin{array}{l}\text { Absolute } \\
\text { Relief (Ra) }\end{array}$ & GIS Software & & 646 & 601 \\
\hline $\begin{array}{l}\text { Relative } \\
\text { Relief Ratio } \\
\text { (Rhp) }\end{array}$ & $\mathrm{Rhp}=\mathrm{H}^{*} 100 / \mathrm{p}$ & $\begin{array}{c}\text { Melton } \\
(1957)\end{array}$ & 726.81 & 607.03 \\
\hline $\begin{array}{l}\text { Dissection } \\
\text { Index (Dis) }\end{array}$ & Dis $=H / R a$ & $\begin{array}{c}\text { Singh \& } \\
\text { Dubey } \\
(1994) \\
\end{array}$ & 0.8 & 0.79 \\
\hline $\begin{array}{l}\text { Gradient } \\
\text { Ratio (Rg) }\end{array}$ & $\mathrm{Rg}=\mathrm{Es}-\mathrm{Em} / \mathrm{Lb}$ & $\begin{array}{c}\text { Sreedevi et } \\
\text { al, (2009) }\end{array}$ & 0.017 & 0.018 \\
\hline $\begin{array}{l}\text { Watershed } \\
\text { Slope (Sw) }\end{array}$ & $\mathrm{Sw}=\mathrm{H} / \mathrm{Lb}$ & $\begin{array}{c}\text { Sreedevi et } \\
\text { al, (2005) }\end{array}$ & 24.83 & 20.53 \\
\hline $\begin{array}{l}\text { Ruggedness } \\
\text { Number } \\
\text { (Rn) }\end{array}$ & $\mathrm{Rn}=\mathrm{Dd} *(\mathrm{H} / 1000)$ & $\begin{array}{c}\text { Patton \& } \\
\text { Baker } \\
(1976)\end{array}$ & 1.11 & 0.56 \\
\hline $\begin{array}{l}\text { Melton } \\
\text { Ruggedness } \\
\text { Number } \\
(\mathrm{MRn}) \\
\end{array}$ & $\mathrm{MRn}=(\mathrm{H} / \mathrm{A})^{0.5}$ & $\begin{array}{c}\text { Melton } \\
(1965)\end{array}$ & 2.08 & 1.72 \\
\hline $\begin{array}{l}\text { Channel } \\
\text { Gradient in } \\
\mathrm{m} / \mathrm{kms} \text {. } \\
(\mathrm{Cg})\end{array}$ & $\mathrm{Cg}=\mathrm{H} /\left\{(\pi / 2)^{*} \mathrm{Clp}\right\}$ & $\begin{array}{c}\text { Broscoe } \\
\text { (1959) }\end{array}$ & 8.94 & 8.14 \\
\hline
\end{tabular}

Lower values of Rg indicate the moderate relief terrain and main stream flow through plateau. In the study, gradient ratio values of Kulbera and Darighara watersheds are 0.017 and 0.018 respectively (Table 6 ).

\section{Table-VI : Relief Characteristics of the Study Area}

Source: Author's Compilation

\section{CONCLUSION}

In this study, it reveals that the remotely sensed data and GIS based technique is more appropriate than conventional method in assessing the drainage morphometry.

Published By:

Blue Eyes Intelligence Engineering

\& Sciences Publication

DOI:10.35940/ijeat.C2247.0210321

Journal Website: www.ijeat.org

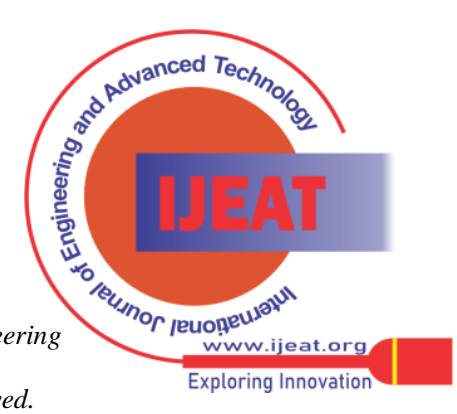


Drainage is the significant elements of landforms study. Its distributional patterns, density, frequency and other basin parameters have been computed and analyzed quantitatively. The morphometric parameters of Kulbera and Daurighara watersheds have been analyzed with respect to drainage density, frequency, bifurcation ratio, stream order, basin shape, circulatory, sinuosity, elongation, infiltration and relief ratio etc. Kulbera and Daurighara watersheds represent dendritic drainage pattern with $4^{\text {th }}$ and $6^{\text {th }}$ order drainage respectively. The bifurcation ratio of Kulbera watershed varies from 4.62 to 7.0 and its value is higher than Daurighara watershed. It indicates that structural disturbances and their drainage pattern have been distorted due to geological and structural rocks of the watershed of Kulbera compare to daurighara watershed. Due to higher bifurcation ratio value of Kulbera watershed, water will take shorter time to reach the outlet and higher is the peak discharge which leads a high probability of flooding than Daurighara watershed. Drainage texture values of Kulbera and Daurighara watersheds are found 3.85 and 4.7 respectively. It indicates coarse drainage texture of Kulbera and moderate drainage texture of Daurighara. In respect of drainage texture, Kulbera and Daurighara watersheds indicate gentle to steep slope terrain, moderate vegetation and less permeable rocks with medium rainfall. Infiltration number of Kulbera watershed (4.92) is little higher than Daurighara watershed (4.55) which indicates lower infiltration and high surface runoff than Daurighara watershed. Rho coefficient value of Daurighara watershed is little higher than Kulbera watershed which means that Daurighara watershed is higher hydrologic storage during floods compare to Kulbera watershed. Texture ratio has determined the groundwater recharge capacity. Daurighara watershed (3.54) is higher groundwater recharge capacity than Kulbera watershed (3.07). Form factor ratio of Kulbera and Daurighara watersheds are 0.28 and 0.30 respectively which indicate that Kulbera watershed has elongated shape with longer duration of flow than Daurighara watershed. In respect of length of overland flow (Lg), Kulbera watershed has high surface runoff, low permeability and steep to very steep slope than Daurighara watershed. The morphometric parameters have been extracted from the SRTM based DEM data using GIS techniques and it provides very important input parameters for watershed prioritization and planning. The collected information from the watersheds can be used further for watershed prioritization, planning and decision making and flood disaster risk reduction.

\section{ACKNOWLEDGEMENT}

The author is thankful to my colleague, Dr. Ananta Gope, Associate Professor, Vivekanada Mahavidyalaya, Burdwan for motivating to do this research work. I am also grateful to him for minutely checking and correction of this paper.

\section{REFERENCES}

1. A. Javed, M.Y. Khanday, R. Ahmed, "Prioritization of Sub-Watersheds Based on Morphometric and Land Use Analysis Using Remote Sensing and GIS Techniques", Journal of the Indian Society of Remote Sensing, vol. 37, No. 2, pp. 37-261, Jun. 2009.

2. P. K., Rai, V.N. Mishra, K. Mohan, "A Study of Morphometric Evaluation of the Son Basin, India Using Geospatial Approach", Remote Sensing Application: Society and Environment, Vol. 7, pp.9-20, Aug. 2017a.

3. P.K., Rai, P.K., Chaubey, K., Mohan, P. Singh, "Geoinformatics for Assessing the Inferences of Quantitative Drainage Morphometry of the Narmada Basin in India", Applied Geomatics (Springer), Vol. 9, No. 3, pp. 1-23, Sept. 2017b.

4. K. Prakash, D. Rawat, S. Singh, et al., "Morphometric Analysis Using SRTM and GIS in Synergy with Depiction: A Case Study of the Karmanasa River Basin, North Central India” Appl Water Sci., Vol. 9, No. 8, pp. 9-13, Jan. 2019.

5. C. S. Agarwal, (1998) "Study of Drainage Pattern through Areal Data Naugarh area of Varanasi district U.P." Journal of the Indian Society of Remote Sensing, Vol. 26, No. 4, pp. 169-175, Dec. 1998.

6. G. P., Obi, G. P., Reddy, A. K. Maji, K. S. Gajbhiye, "GIS for morphometric analysis of drainage basin" Journal of Geological Survey of India, Vol. 11, pp. 9-14, Sept. 2002.

7. S. Rais, A. Javed, "Drainage characteristics of Manchi basin, Karauli district, Eastern Rajasthan using remote sensing GIS techniques", International Journal of Geomatics and Geoscience, Vol. 5, No. 1, pp. 285-299, Mar. 2004.

8. L. P. Perucca, Y. E., Angilieri, "Morphometric Characterization of del Molle Basin Applied to the Evaluation of Flash Floods Hazard, Iglesia Department, San Juan, Argentina" Quaternary International Journal, Vol. 8, No. 7, Aug. 2010.

9. E.B. Eze, j. Efiong, (2010) "Morphometric Parameters of the Calabar River Basin: Implication for hydrologic processes", Journal Geography and Geology, Vol. 2, No. 1, pp. 18-26, Jan. 2010.

10. S. Singh and A. Dubey, (1994). Geo-environmental Planning of Watersheds in India. Allahabad. Chugh Publications, pp. 28-69.

11. A.N. Strahler (1964). Quantitative Geomorphology of Drainage Basin and Channel Network. Handbook of Applied Hydrology, pp. 39-76.

12. A. Javed, M.Y. Khanday, S. Rais, "Watershed Prioritization using Morphometric and Landuse/Landcover Parameters: A Remote Sensing and GIS Approach” Journal of Geological Society of India, Vol. 1, No. 1, pp. 78-63, Jul. 2011.

13. M.Y. Khaday, A. Javed, "Prioritizatio of Sub-Watersheds for Conservation Measures in a Semi-arid Watershed using Remote Sensing and GIS", Journal of Geological Society of India, Vol. 88, No. 2, pp. 185-196, Aug. 2016.

14. C. Pande, K. Mohar, R. Pande, "Assessment of Morphometric and Hypsometric Study for Watershed Development using Spatial Technology: A case study of Wardha River Basin in Maharastra, India” International Journal of River Basin Management, Vol. 16, No. 1, Jul. 2018.

15. M.D. Nautiyal, "Morphometric Analysis of a Drainage Basin, Dist. Dehradun, Uttarpradesh", Journal. Indian Society of Remote Sensing, Vol. 22, No. 4, pp. 251-261, Dec. 1994.

16. R. Kumar, S.Venkatesh, S. M. Rajasekar, I. Muthuchamy, "Morphometric Analysis and Prioritization of Palathodi Watershed in Parambikulam-Aliyar Basin, Tamil Nadu using RS and GIS”. Asian Journal of Environmental Science, Vol. 11, No. 1, pp. 51-58, Jun. 2016.

17. Bates, R.L. and Jackson, J.A. (1980) Glossary of Geology. American Geological Institute, pp. 751.

18. A. N. Strahler, V. T. Chow, (1964). Quantitative Geomorphology of Drainage Basins and Channel Network. Edited In Ven Te Chow, Handbook of Applied Hydrology, McGraw Hill Book Company, New York, pp. 39-76.

19. S. N. Sing Mura, "Identification of Water Resource Potential Zones of Karu River Basin Using Remote Sensing and GIS techniques in Purulia District, West Bengal, India", Infokara Research Journal, Vol. 9, No. 2, pp. 589-605, Feb. 2020.

20. Leopold, W.B. and Leopold, L.B. (1966) River Meanders - Theory of Minimum Variance. U.S. Geol. Survey Prof., pp. 15.

21. K. Pareta, U. Pareta, "Quantitative Geomorphological Analysis of a Watershed of Ravi River Basin, HP India", International Journal of Remote Sensing and GIS, Vol. 1, No. 1, pp. 41-56, May 2012.

22. U. Ali, S.A. Ali, “Analysis of Drainage Morphometry and Watershed Prioritization of Romushi-Sasar Catchment, Kashmir Valley, India using Remote Sensing and GIS technology", Journal of Advanced Research, Vol. 2, No. 12, pp. 5-23, Dec. 2014.

23. R.E. Horton, "Erosional Development of Streams and their Drainage Basins; Hydrology Approach to Quantitative Methodology”,. Bulletin of the Geological Society of America, Vol. 56, pp. 275-370, Mar. 1945.

Published By:

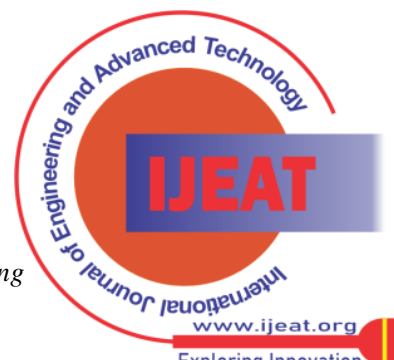


24. C. P., Chitra, K. Alaguraja, D. Yuvaraj, M. Manivel, "Watershed Characteristics of Kundah Sub-Basin using Remote Sensing and GIS Techniques", International Journal of Geomatics and Geoscience, Vol. 2, No. 1, pp. 311-335, Jan. 2011.

25. K. Pareta, "Geo-environmental and Geo-hydrological Study of Rajghat Dam Sagar, Madhya Pradesh using Remote Sensing techniques" International Journal of Scientific and Engineering Research, Vol. 2, No. 8, pp. 1-8, Aug. 2011.

26. S. A. Schumm, "Evolution of Drainage Systems \& Slopes in Badlands at Perth and Boy, New Jersey", Bulletin of the Geological Society of America, Vol. 67, pp. 597-646, May 1956.

27. T. Chow Ven, (1964). Handbook of Applied Hydrology. McGraw Hill Inc, New York.

28. R. Chopra, D.D Sharma "Morphometric Analysis of Sub-Watersheds in Gurudaspur District, Punjab, using Remote Sensing and GIS Techniques", Journal of Indian Society of Remote Sensing, Vol. 33, No. 4,, pp. 531-539, Dec. 2005.

29. S. A. Sharma, S. Gajbhiye, R.K. Nema and S. Tignath, "Assessing Vulnerability to Soil Erosion of a Watershed of Narmada Basin using Remote Sensing and GIS", International Journal of Science and Innovative Engineering Technology, Vol. 1, Jan. 2015.

30. A.Javed, , M.Y. Kanday, R.Ahmed, "Prioritization of Sub-watershed Based on Morphometric ad Landuse Analysis using Remote Sensing and GIS Techniques", Journal of Indian Society of Remote Sensing, Vol. 37, No. 2, pp. 261, Oct. 2009.

31. K.N. Ratnam, Y.K. Srivastava, V.V. Rao, E. Amminedu, K. S. R. Murthy, "Check Dam Positioning by Prioritization of Micro Watershed using SYI Model and Morphometric Analysis - Remote Sensing and GIS Perspective", Journal of Indian Society of Remote Sensing, Vol. 33, No. 1, pp. 25-38, March 2005.

32. V.C. Miller, (1953).A Quantitative Geomorphic Study of Drainage Basin Characteristics in the Clinch Mountain area, Virgina and Tennessee. Columbia University, Department of Geology, ONR, New York, pp. 389-402.

33. J. E. Mueller, "An Introduction to the Hydraulic and Topographic Sinuosity Indexes" Annals of the Association of American Geographers, Vol. 58, No. 2, pp. 371-385, Jun. 1968.

34. K. N. Singh, (1980). Quantitative Analysis of Landforms and Settlement Distribution in Southern Uplands of Eastern Uttar Pradesh (India). Vimal Prakashan, Varanasi.

35. R.J. Chorley, (1969). Introduction to Physical Hydrology. Methuen and Co. Ltd. Suffolk, pp. 211.

36. Z. Macka, "Determination of Texture of Topography from Large Scale Contour Maps", Geografski Vestnik, Vol. 73, No. 2, pp. 53-62, Jan. 2001.

37. H.Ozdemir, D. Bird, "Evaluation of Morphometric Parameters of Drainage Network Derived from Topographic Maps and DEM in Point of Floods", Environmental Geology, Vol. 56, No. 7, pp. 1405-1415, Feb. 2009.

38. S. K. Nag, "Morphometric Analysis using Remote Sensing Techniques in the Chaka Sub-watershed, Purulia district, West Bengal", Journal of Indian Society of Remote Sensing, Vol. 26, No. 1\&2, pp. 69-76, Mar. 1998.

39. K. G. Smith, "Standard for Grading Texture of Erosional Topography", American Journal of Science, Vol. 248, No. 9, pp. 655-668, Sept. 1950

40. V. S. Kale, A. Gupta (2001). "Introduction to Geomorphology. Academic (India) Publishers, New Delhi,

41. J. C. Dornkamp, C. A. M. King, (1971). Numerical Analyses in Geomorphology, an introduction. St. Martins Press, New York, v.72, pp. 372.

42. P. K. Rai, R. C. Chandel, V. N. Mishra, P. Singh, "Hydrological Inferences through Morphometric Analysis of lower Kosi River Basin of India for Water Resource Management Based on Remote Sensing Data”, Applied Water Science (Springer), Vol. 8, No. 15, pp. 1-16, Jan. 2018.

43. R. Suresh (2010). Soil and Water Conservation Engineering Watershed Concept and Management. Standard Publishers Distributors, New Delhi.

44. K. S. Muthukrishnan, K. K. Banu, "Drainage Morphometry Evaluation for Kodavanar Sub-basin to Understand the Interrelationship in Morphological Systems and in Process-Response Systems", International Journal of Geomatics and Geoscience, Vol. 3, No. 4, pp. 692-707, Dec. 2013.

45. A. N. Strahler "Quantitative Analysis of Watershed Geomorphology", Transaction American Geophysical Union, Vol. 38, No. 6, pp. 913-920, Dec. 1957.

46. M. A. Melton, (1965) "The Geomorphic and Paleoclimatic Significance of Alluvial Deposits in Southern Arizona", J Geol, Vol. 73, No. 1, pp. 1-38, Jan. 1965.

Published By:

Blue Eyes Intelligence Engineering

\& Sciences Publication

(C) Copyright: All rights reserved.
47. M. Deen, (1982) Geomorphology and Landuse: A Case Study of Mewat. Thesis (PhD), JNU, New Delhi.

48. P. D. Sreedevi, S. Owais, H. H. Khan, S. Ahmed, (2009) "Morphometric Analysis of a Watershed of South India using SRTM Data and GIS", J Geol Soc India, Vol. 73, No. 4, pp. 543-552, May 2009.

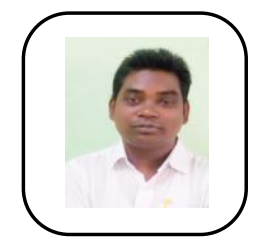

Dr. Shambhu Nath Sing Mura is an assistant professor in Geography of Vivekananda Mahavidyalaya, Burdwan, West Bengal, India. He is now working as a teacher in last 10 years. His $\mathrm{Ph}$. D. degree entitled "Land and Water Resource Management for Sustainable Development in Purulia District, West Bengal" from The University of Burdwan in 2015. He has published more than eight research paper and book chapter in national and international level. He is an expert of Remote Sensing (RS) and Geographical Information System (GIS) in the field of geography. In present, he has worked on watershed management, water resource management, water quality assessment and water potentiality in the semi-arid western part of West Bengal, India. He has used various remote sensing and geographical information system software for satellite image processing and gis data analysis such as ArcGis, MapInfo, Ilwis, Qgis and Smart GIS in the research work.

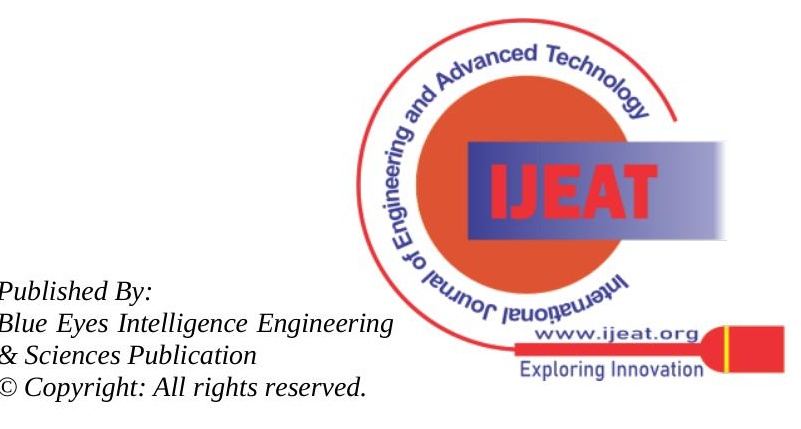

